\title{
Evaluation of the appearing changes in water regime at Ráztoka and Červík basins in the Beskydy Mts.
}

\author{
M. Tesař, J. Buchtele
}

Institute of Hydrodynamics AV ČR, v.v.i., Pod Pat'ankou 30/5, 16612 Praha 6, CZ, E-mail:tesarihas@iol.cz

\begin{abstract}
Tesař M., Buchtele J. 2013: Evaluation of the appearing changes in water regime at Ráztoka and Červík basins in the Beskydy Mts. - Beskydy, 6 (2): 135-148

The influence of vast salvage clear cutting in some hilly regions induced by acid rains is sometimes considered as a significant contribution to the disastrous character of the recent floods. Then the considerations having also partly emotional character, appeared, namely after large floods in the Morava and Odra Rivers in the July 1997 and in the Labe River basins in August 2002. The simulations of rainfall-runoff process for several experimental catchments have been carried out using daily time series up to 50 years long. The outputs of hydrological models SAC-SMA and BROOK' 90 provide naturally the differences between observed and simulated discharge, which could show the tendencies in the runoff. They have been analysed and findings indicate the increases of runoff after deforestation. The differences between observed and simulated flows can be helpfulalso for the assessment of changes in evapotranspiration demands as the significant long-termed phenomenon.
\end{abstract}

Key words: runoff change, salvage clear cutting, modelling of rainfall-runoff process

\section{Introduction}

In the past year it has been already 10 years after the disastrous floods in the Labe River and 15 years after extensive flooding in the Moravia catchments. And besides that, it could be reasonable to remember some recent local summer period flood in the north Bohemia, denoted sometimes as the flash floods. Besides that in the year 2011 the low precipitation in the summer and autumn half-year caused dry periods with the decreased water resources, and the expectations appeared of the lack of drinking water sources. Both these situations remind that the attention is desirable to the areal and time variability of water resources in the hollows of Czech territories with specific geographic conditions.

The orographic precipitation are well-known in the areas of the Beskydy Mts. and of the Jeseníky Mts. and these hills may be felt as the region influenced by the distinct atmospheric circulations, i. e. of the air flowing in the Moravian valleys; and/or in the area denoted the Moravian Gate. In this context it may be proper to notice the some similarity and distinction of cyclones trajectories, which have caused the two mentioned harmful floods. This circumstance has influenced the intention to incorporate into the evaluation of water regime in the Beskydy Mts. also some results from experimental catchments in the Labe River basin, which are here partly used, included in Table 1 . The purpose is to take into account somehow the significant phenomena, with the regional characters and consequences.

The care devoted to the phenomenon of floods mentioned above appears as a permanent task and for two named disastrous flood cases extensively were evaluated (Brázdil et al. 2005); the genesis, evolution and consequences have been there presented, and are still to be reminded. 


\section{The natural processes in forests relevant for the considerations in modelling}

What is to be interesting frequently is that Mediterranean could be considered as the area, where the trajectories of cyclones started. It is valid for the both exceptional floods, in the year 1997 and in the year 2002 (see Fig. 1), i.e. the usual type $\mathrm{Vb}$ according van Bebber, (Brázdil et al. 2005). The attention to the atmospheric currents and formations in hydrological analyses has been reminded in the first half of the past century also for the central Europe (Schaffernak 1935). Undoubtedly the orography role of the Alps is usually substantial, nevertheless the differences between Moravian vales and Bohemian territory with the character of the hollow could be the reason for the comparison of catchments in the flysh area and with crystalline bedrocks, i.e. with too diverse geomorphology, included in Table 1.

There are the serious and diverse natural phenomena requiring the attention and evaluation in the efforts to improve the clarification of the influences on the variability of runoff:

- the climatic oscillation, frequent and more or less regular; and decisive phenomena are the precipitation and evapotranspiration by the water consumption, while e.g. Beer (2005) is showing clearly the correlation of solar activity and climate variability, and some like fluctuations have been pursued also quite recently (Buchtele, Tesař 2009a);

- long-term evolution of vegetation cover, including too its possible abrupt changes, i. e. also the extraordinary winds disasters and even insects damages (such event appeared in this country during the second half of $19^{\text {th }}$ century (Jelínek 1985), probably as the sig-

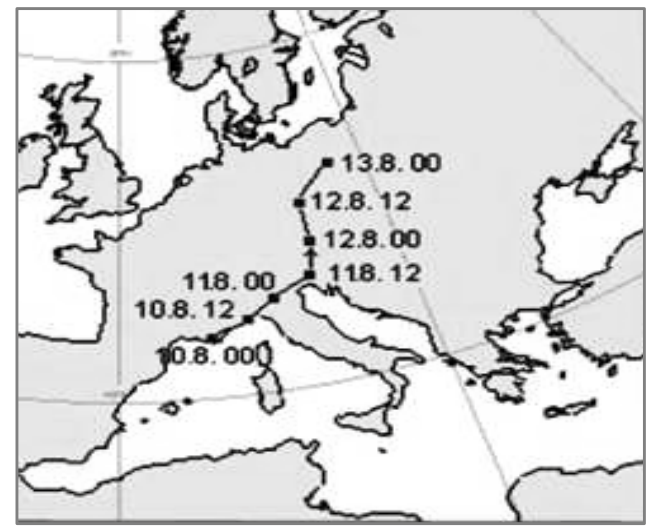

Labe 2002 nificant events for sensitive evaporation), and precipitation or runoff event (Buchtele et al. 2004) and for the changing volumes of water losses (Brandt et al. 1988);

- significant and flexible geomorphologic conditions, or the seeming random diverse appearing events, as due to the growing agricultural production (Keller 1970), the processes of erosion etc.

In the context with these three circumstances for the surface runoff rise it could be probably remarkable to remind some higher occurrence of conspicuous floods in the last decade of $19^{\text {th }}$ century also relatively shortly after above mentioned drastic natural devastating events. In the entirety these are the primary hazardous processes for the assessments of activity of evapotranspiration and should obtain adequate care. In the actual circumstances the runoff simulation seems to be the suitable solution.

The rainfall - runoff models, which have been extensively implemented for different catchments may provide as the outputs also the simulated evapotranspiration; and secondly subsurface water storage with a grasp is obtained. These are the convenient results of modelling runoff, with its several components. That clearly illustrates the high contribution of the sub-surface water storage to the runoff, also in the hilly region, but too for the appreciation of the mentioned alluded complex evapotranspiration.

Therefore the situations in the given region, i.e. in the Beskydy Mts., may be so well perceivable namely in this connection with the basins in other geomorphologic conditions, i. e. by the comparisons for diverse natural variability. So, besides the experimental catchments Ráztoka and Červík located in the Beskydy Mts., the

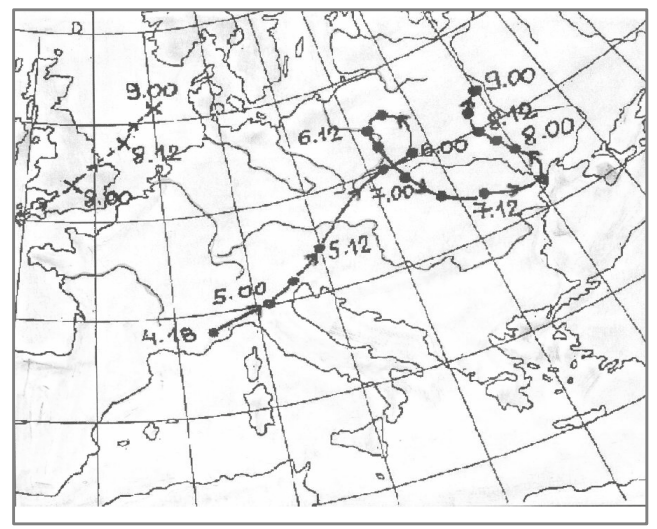

Morava 1997

Fig. 1: Trajectories of cyclones during rainfalls of disaster floods (Labe 2002; Morava 1997). 
similar basins Modrý potok and Liz could be used for resembling needs. Moreover, since the primary attention is the situation in the region of the Beskydy Mts. the water regime at the Bečva River basin with a closing profile at Dluhonice basin $\left(\mathrm{P}=1600 \mathrm{~km}^{2}\right)$ is for some comparison shortly evaluated.

The length of the evaluated time series is usually significant, as it permits to follow then the influences of the vegetation evolution, which affects evapotranspiration demand when daily series are available, e.g. for several decades of years. Modelling of rainfall-runoff process used in submitted experiments provides the possibility to discover the diverse runoff changes in the simulations, which influence evapotranspiration demands and consequently the complex long-term process in water regime.

\section{Tools and data used for experiments}

The simulations of rainfall-runoff process have been carried out using daily time series even approximately 40-50 years long. The catchment area of these basins mostly is between $1 \mathrm{~km}^{2}$ and $3 \mathrm{~km}^{2}$ as it is presented in Table 1. The outputs of two hydrological models of different structure have been implemented in these investigations:

- the rainfall-runoff conceptual model SACSMA-Sacramento Soil Moisture Accounting (Burnash 1995), which is the device for prediction of the river flows in U. S. Weather Service; Figs. 2 and 3 provide as the examples of the useful achievement the comparison of monitored and simulated runoff during large flood and for even one year long period. Besides that the runoff components, which generate the total discharge in diverse catchments with the size, vegetation and geomorphology distinguished are in addition in the upper part of Fig. 4 presented.

- physically based model BROOK'90 (Federer 1995), designed in Forest Service in U. S., it enables to simulate the evapotranspiration with its five components, in which the transpiration is usually the expressive part of this important natural process. Lower part of Fig. 4 illustrates the average proportions of evapotranspiration and the annual course of those components is provided during the period of several years in Fig. 5.

The models as the appropriate tools have been used in several diverse recent experiments, inclusive basins Ráztoka and Červík. The implementation of rainfall-runoff models means for different basins that the natural processes components, representing the climatic variability are essentially comprehend. With the adequate consideration of the above mentioned three kinds of aspects it could be possible and useful to follow just the differences between observed and simulated values; that could be consequential for ascertaining of anticipated changes and/ or trends. Similar approach has been used in other cases (Brandt et al. 1988) and with the data for the catchments in the Beskydy Mts. started modelling recently and the trials with diverse aspects (Buchtele et al., 2004).

The results of simulation accuracy of the SACSMA model implementation are presented in Table 2, where outputs are summarized for the whole periods. The similar evaluations of simulations using SAC-SMA model are for the partial periods, with different vegetation extent due to the consecutive forest changes, and/or caused by the young forest cover (Buchtele et al. 2009).

In the context with the mentioned evapotranspiration as gained using BROOK' 90 model it is possible to obtain besides the monthly outputs presented in Fig. 5 also the results for the daily time interval, as further Fig. 10 illustrates that with the smoothed discharges differences. The awareness of possibilities of this tool appears as well evident, e.g. for the assessment of the role of vegetation change in the runoff changes (Armbruster et al. 2004).

Tab. 1: Basic characteristics of the main basins.

\begin{tabular}{|c|c|c|c|c|c|c|}
\hline Basin & Area $\left[\mathbf{k m}^{2}\right]$ & Period [years] & $\begin{array}{r}\text { Hmin } \\
{[\mathrm{m}}\end{array}$ & $\underset{1 .]}{H \max }$ & \multicolumn{2}{|c|}{$[\mathrm{mm} /$ year $]$} \\
\hline Ráztoka - Beskydy Mts. & 2.08 & $1953-2001$ & 602 & 1084 & 923 & 1243 \\
\hline Červík - Beskydy Mts. & 1.85 & $1953-2001$ & 640 & 961 & 648 & 1125 \\
\hline Modrý potok - Giant Mts. & 2.62 & 1993-2006 & 1010 & 1554 & $1831^{*}$ & 1488 \\
\hline $\begin{array}{l}\text { Liz - Šumava Mts. } \\
\text { (Bohemian Forest) }\end{array}$ & 0.99 & 1984-2006 & 828 & 1024 & 324 & 851 \\
\hline
\end{tabular}

*) Extraordinary high values due to the snow measurement and deposits shifting by winds 

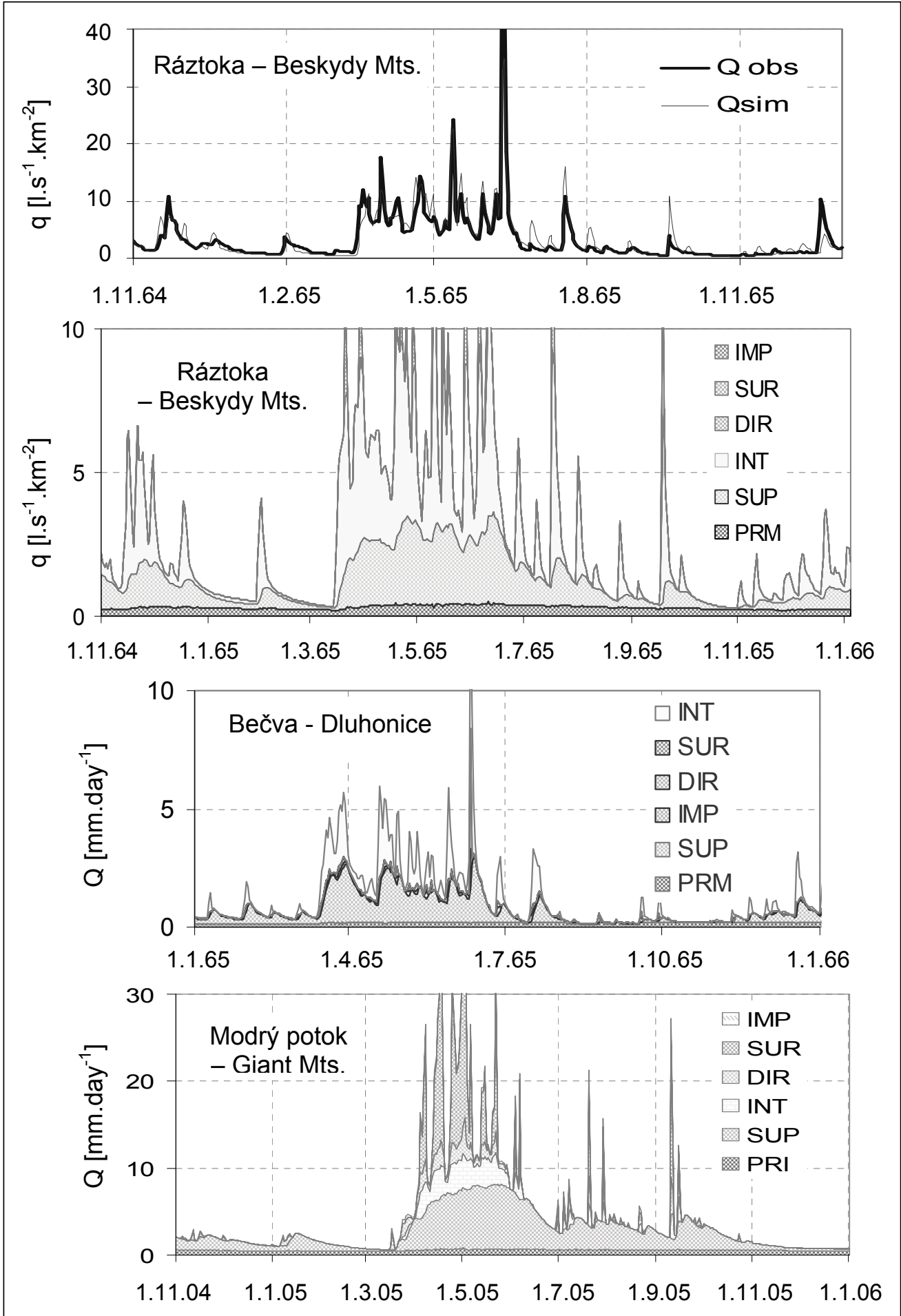

Runoff components: baseflow: primary, supplementary; interflow, other runoff: direct, surface, from impervious areas

Fig. 2: Observed and simulated discharges and the runoff modeled components 


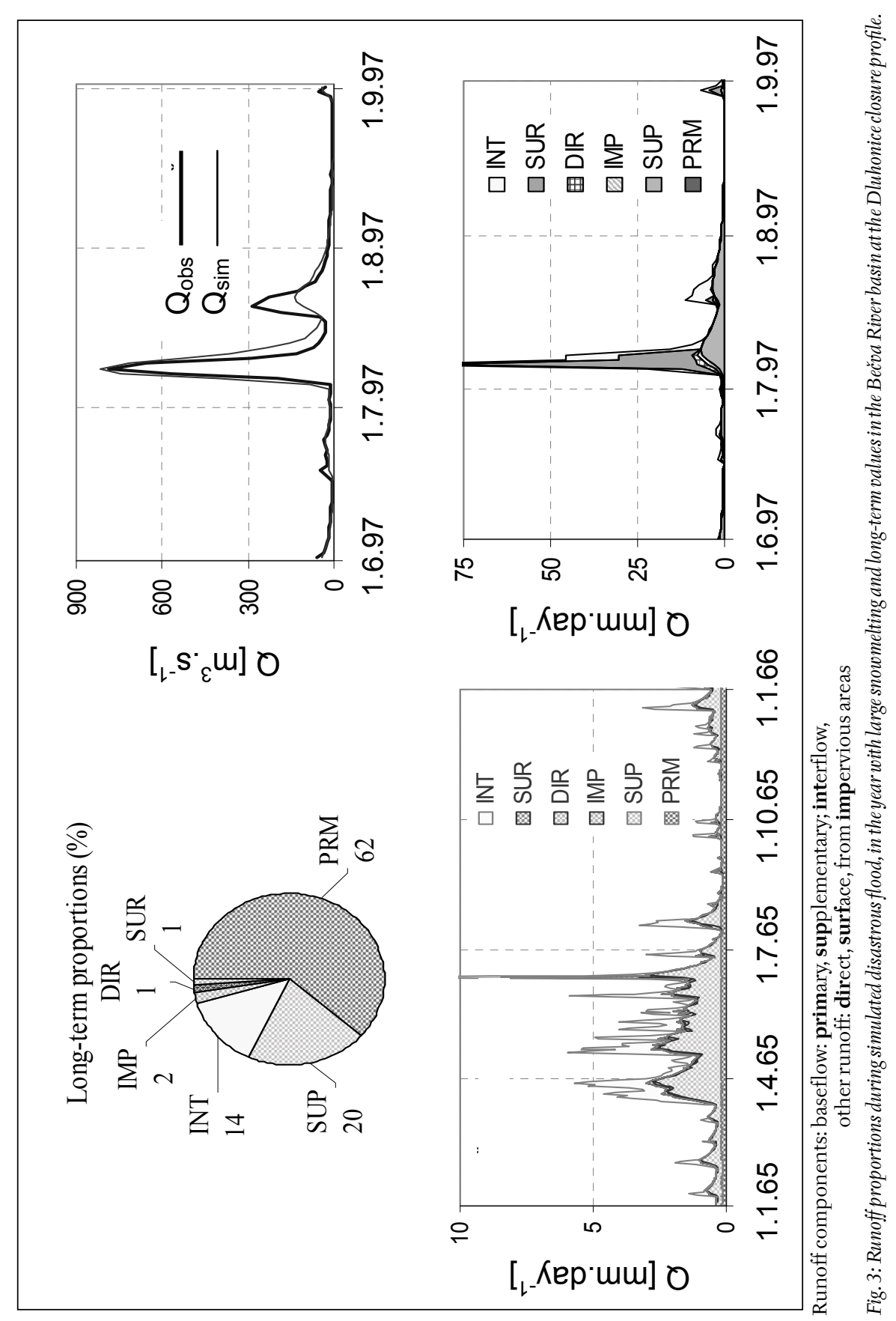


Tab. 2: The accuracy of simulation using SAC-SMA model.

\begin{tabular}{lccc}
\hline \multicolumn{1}{c}{ Basin } & R & $\Delta$ & ABs. DIF (\%) \\
\hline Ráztoka - Beskydy Mts. & 0.8549 & -0.05 & 23.99 \\
Červík - Beskydy Mts. & 0.7452 & 0.06 & 24.82 \\
Modrý potok - Giant Mts. & 0.8479 & 0.12 & 21.27 \\
$\begin{array}{l}\text { Liz - Šumava Mts. } \\
\text { (Bohemian Forest) }\end{array}$ & 0.8192 & 0.08 & 18.07 \\
\hline
\end{tabular}

R...Correl. coef. between $\mathrm{Q}_{\text {obs }}$ and $\mathrm{Q}_{\text {sim }}$

$\Delta \ldots \mathrm{dQ}=\mathrm{Q}_{\mathrm{obs}}-\mathrm{Q}_{\text {sim }}$

ABS. DIF... absolute standard monthly error

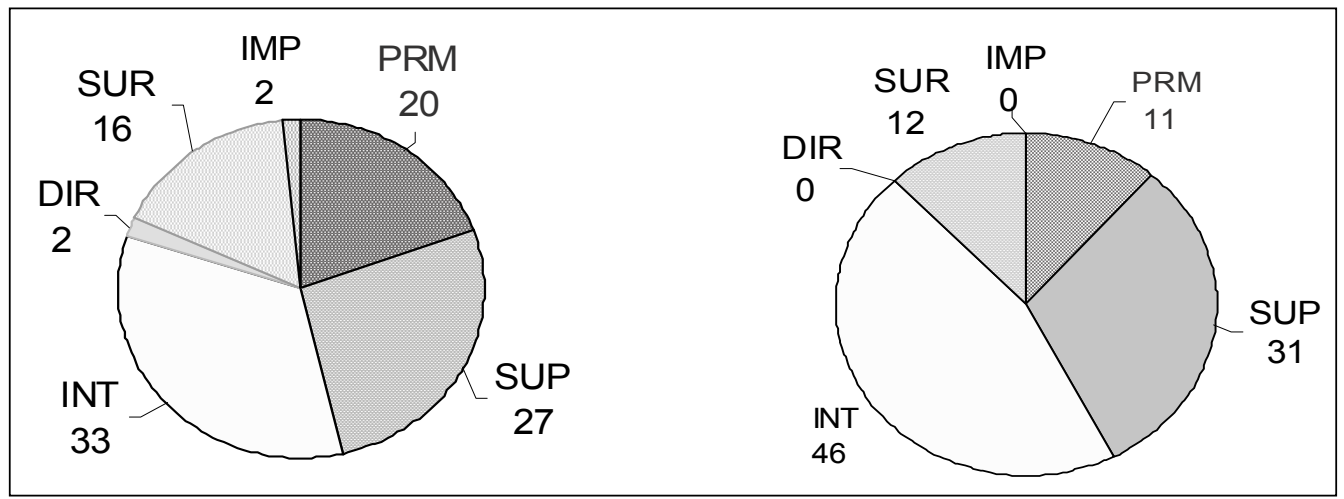

baseflows: primary, supplementary, interflow

other outflows: direct, surface, from impervious areas

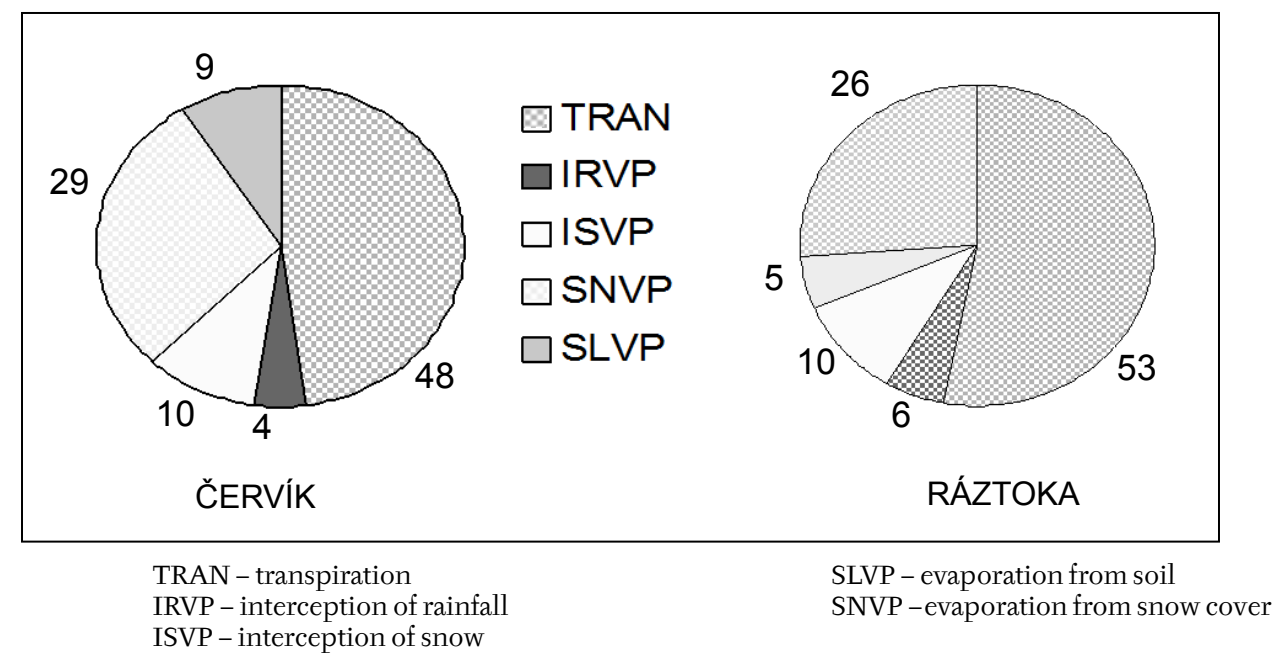

Fig. 4: Runoff and evapotranspiraton components of the basins in the Beskydy Mts. for the whole time period (\%). 
The changes of water regime pursued in the experimental basins Červík and Ráztoka is not an easy or simple task. This first basin is covered by coniferous forest, in Ráztoka there were prevailing deciduous trees. The auspicious condition is that daily time series of precipitation, air temperature and runoff used for evaluation are just more than 50 years long; and for Bečva River basin at Dluhonice (with $\mathrm{P}=1600 \mathrm{~km}^{2}$ ) 40 years have been available. The relatively long series have been used as the input for simulations of rainfall-runoff process, and the trends of differences between observed and simulated runoff $\left(\mathrm{dQ}=\mathrm{Q}_{\mathrm{obs}}-\mathrm{Q}_{\mathrm{sim}}\right)$ have been moreover compared with the courses of annual volumes of the wood production (Fig. 6).

The influence of changes in forest for the runoff is well evident and apparent also in the difference between kinds of woody species. Decreasing of some changes, i.e. the affecting of runoff seems to be visible with stopping woods cutting, probably due to the increasing evapotranspiration, again appearing with new vegetation. Such influences have seemed appearing in differences during calibration of rainfall-runoff model for the recent four separate periods (Buchtele et al. 2004). The mentioned changes of volumes of woods in the basins are presented in the upper part of Fig. 6.

\section{Results and discussion of simulation outputs}

The simulation of rainfall-runoff process is prepared for diverse experimental basins and for another relatively larger catchments with significant need of attention to water commonly watched and/or firstly watched. That provides different information for the assessments of future situation in the forested area. The rainfallrunoff model SAC-SMA distinguishes and provides as the outputs altogether six components of total runoff, as Fig. 2 illustrates it, and similar stage is with the evapotranspiration, which is illustrated in Fig. 4 and also in Fig.5., where both processes the runoff and evapotranspiration are displayed.

The differences between observed and simulated flows $\left(\mathrm{dQ}=\mathrm{Q}_{\mathrm{obs}}-\mathrm{Q}_{\mathrm{sim}}\right)$ show clear influence of clear cutting on the variability of runoff, and the proportions of its six components, which are included in Fig. 2 and also Fig 3, what affects the amount of evapotranspiration, too. The second used model BROOK' 90 provides as the outputs also the simulated evapotranspiration, with five components: transpiration, rainfall and snow interception, soil and snow evaporation, presented in Fig. 4 and also in Fig. 5.

Subsurface water storage represents frequently the decisive part for the discharge in small as well as in great streams, what depends frequently on geomorphology of the basin. The simulation for the evaluated basins permits to judge that the subsurface outflow - consisting from three components (primary, supplementary and interflow) - may produce in the annual cycle up to $70 \%$ of annual runoff, as also Fig. 2 allows to consider as the realistic matter and what is further documented in data from basin Modrý potok (Buchtele, Tesař 2009a). But during July 1997, even with the disastrous flood, the proportions of the surface- and groundwater were entirely adverse (Fig. 3 and 11).

Evapotranspiration as the process, which affects significantly subsurface water is the process, which is included deeply in the modelling of rainfall-runoff. The look at that role in that context may provide Fig. 4, which shows namely proportions of transpiration and interception and in this way the effect of diversified vegetation cover and/or climatic conditions.

Evapotranspiration affecting the interaction with soil water is explicit and some view at that role may be visible moreover in Fig. 5. It shows besides proportions of transpiration and rain interception also the effects of divergence in

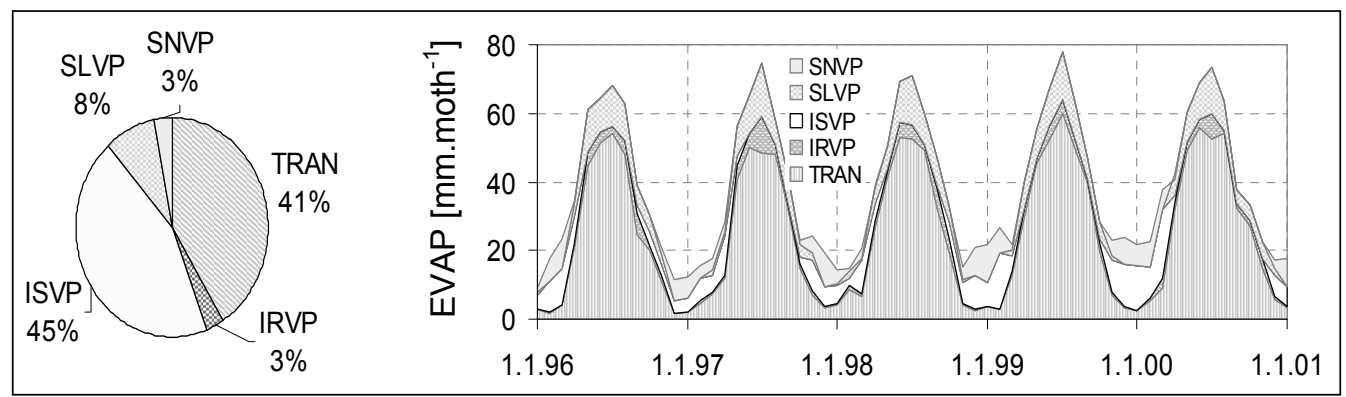

Fig. 5: Annual proportions of evapotranspiration components and amounts in the Ráztoka basin for the time period from 1.1. 1996 to 31.12. 2000. 

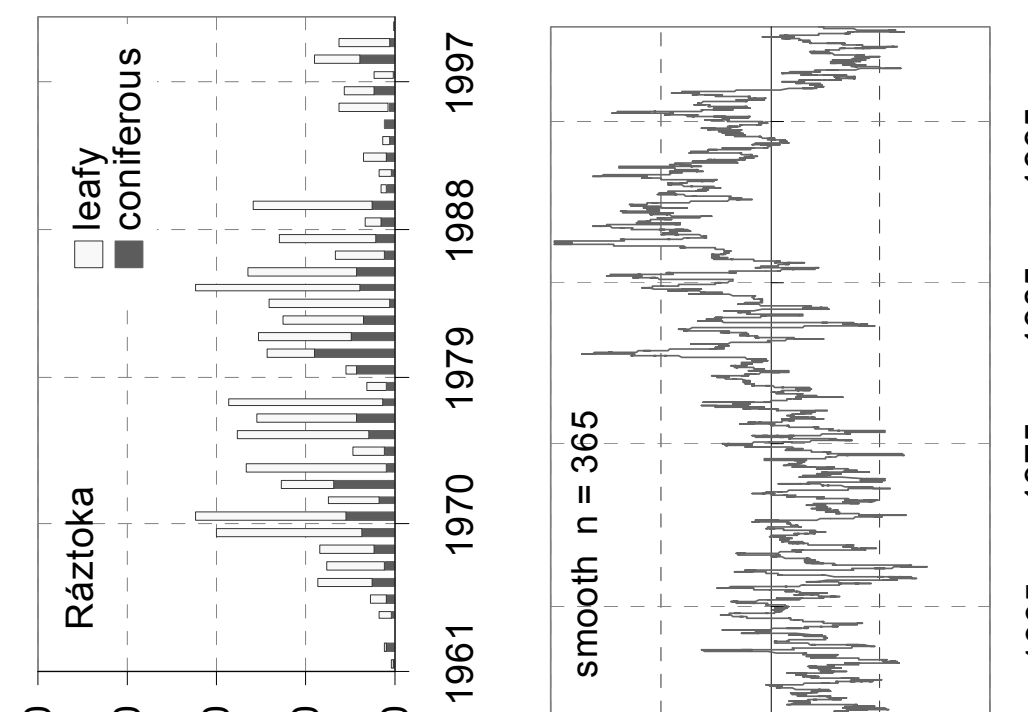

คำ

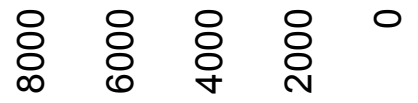

옹

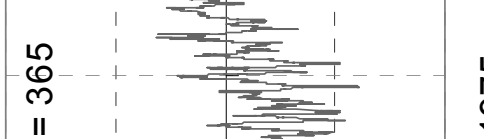

ని

으

ᄃ

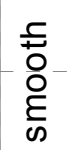

5

5

ฮั

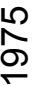

กึ

${ }_{\varepsilon} m$
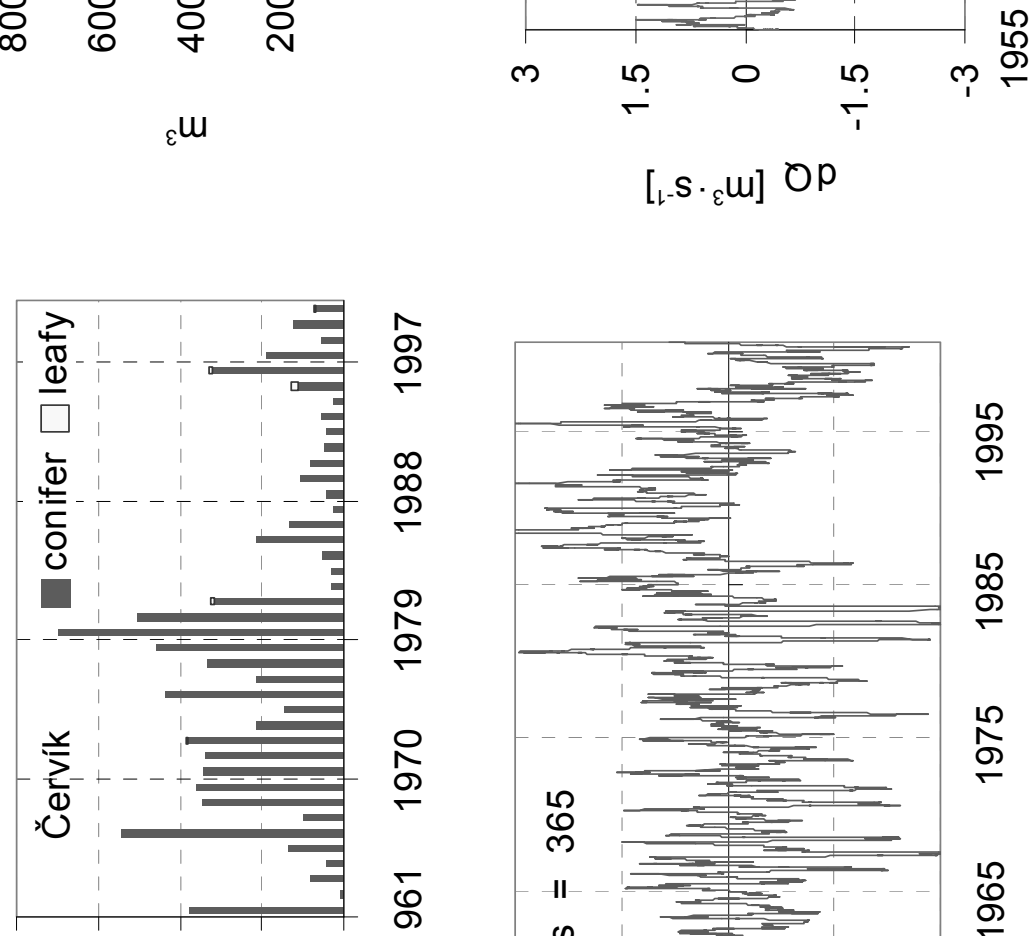

ลิ

$\left[{ }_{1-S} \cdot{ }_{\varepsilon} m\right] O P$

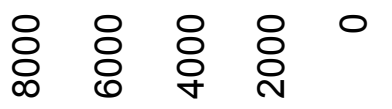

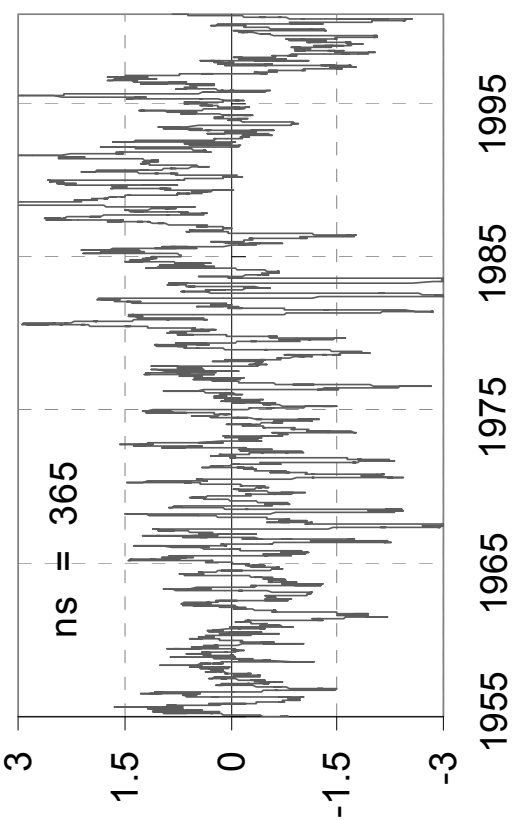

$\left[{ }_{l}-S \cdot{ }_{\varepsilon} w\right] O P$

คุ

న

م

옴

ฮุ

${ }_{\varepsilon} w$

$\stackrel{\infty}{\infty}$

क

ڤึ

กึ 


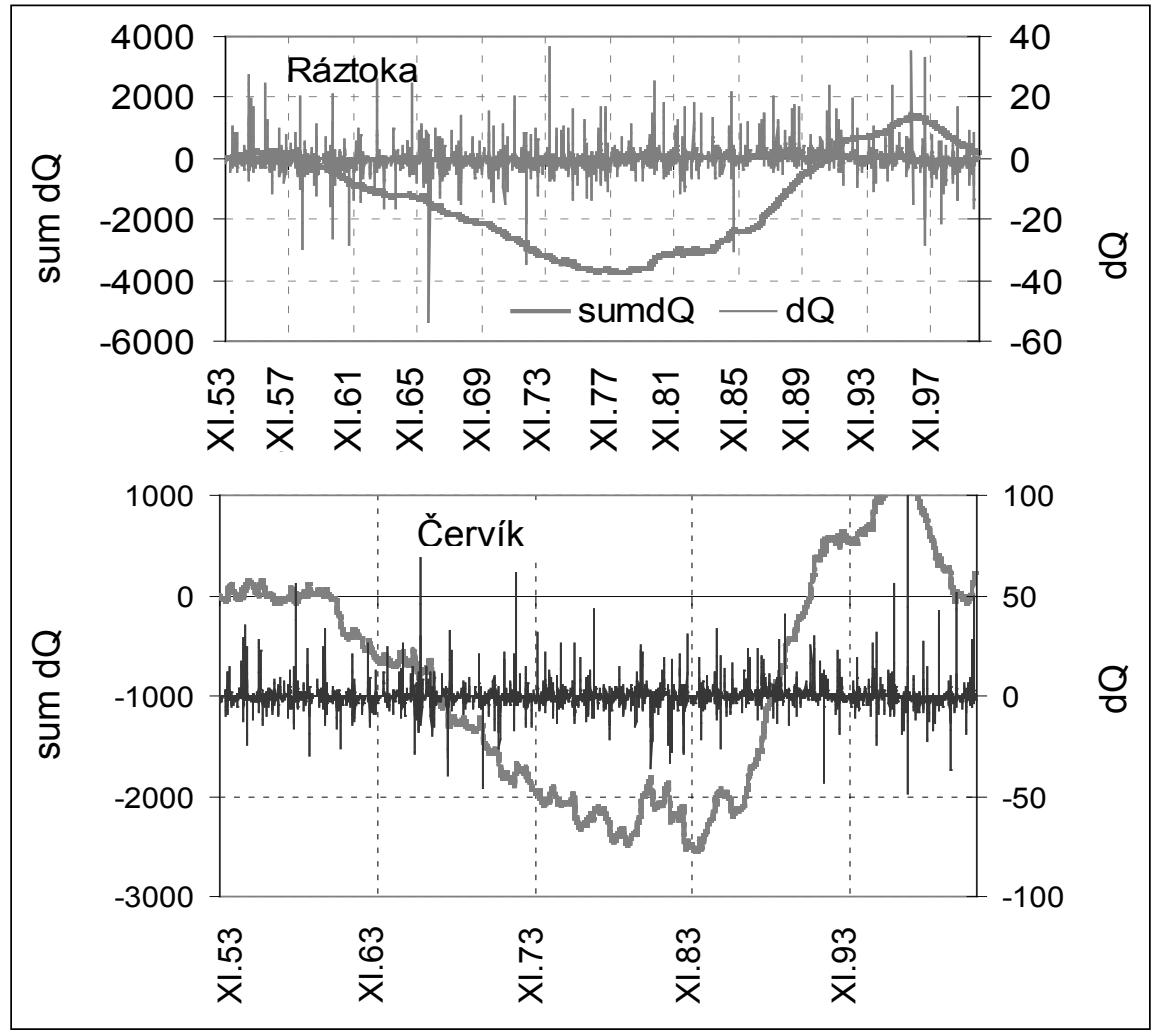

Fig. 7: Differences between monitored and observed runoff (dQ) and accumulated values (sum dQ).

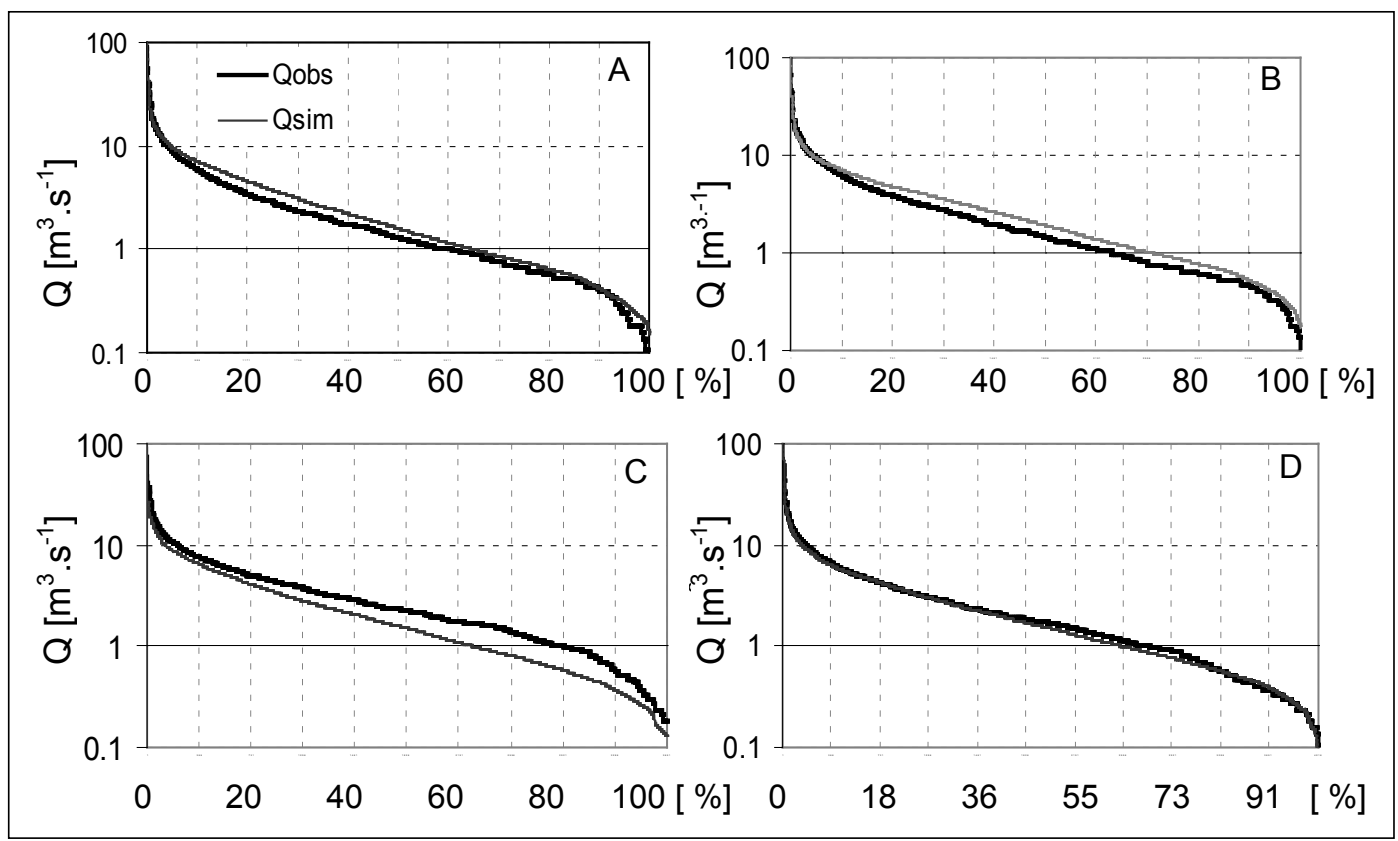

Fig. 8: Flow duration curves of observed and simulated discharges of the Ráztoka basin for several decades with diverse extension of forest cover. (A: 1953-1969, B: 1970-1979, C: 1980-1989, D: 1990-2000). 


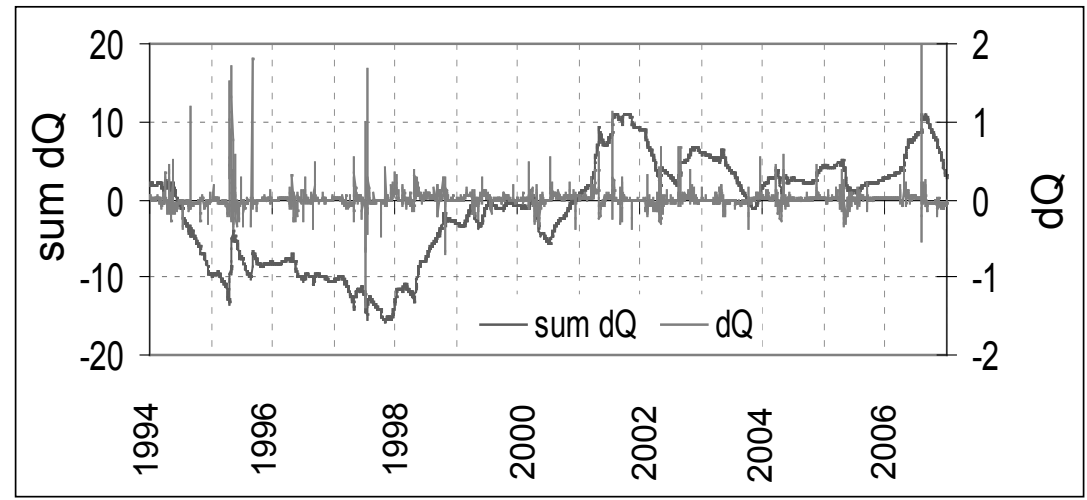

Fig. 9a: Fluctuation of differences between monitored and simulated runoff (dQ) and accumulated values (sum dQ) of the Modry potok basin in the Giant Mts. (1 ${ }^{\text {st }}$ January)

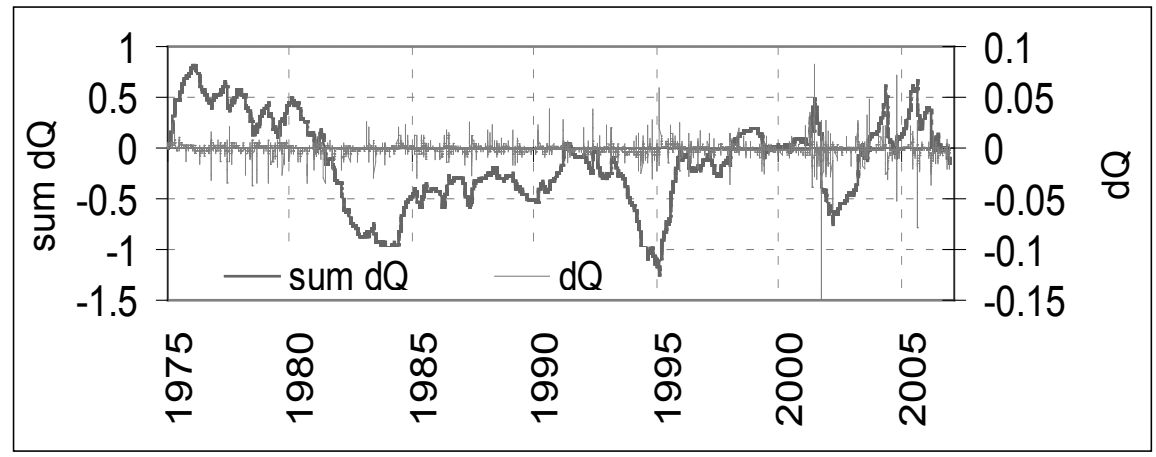

Fig. 9b: Variability of differences $d Q$ and sum dQ of the Liz basin in the Šumava Mts. (1 $1^{\text {st }}$ November)

vegetation cover due to climatic conditions. The insects have caused the damages, and it inflicts clearly the decrease of transpiration, as it could be assumed namely from Fig. 5. The prevalence of transpiration is still visible in the comparison with other components of evapotranspiration process, moreover the snow interception creates conspicuous component of total evapotranspiration in the hilly basin.

The variability, oscillation and the changes, as frequent cases appearing in water resources, are depending on different influences. Fig. 6 shows also above mentioned fluctuations, and moreover, it indicates the decreasing outflows in the recent period, this is probably caused by the increase of evapotranspiration due to the growth of vegetation in the newly forested parts of area. Further Fig. 7 presents in comprehensive format the appearing changes, which are able to help in the assessments of the kinds of changes looking either on dQ's or the accumulated values - sum dQ.

However it is worth to declare that the extensively followed differences $d Q=Q_{\text {obs }}-Q_{\text {sim }}$ are sensitive to such events as the forest disasters appears, caused namely by winds and/or insects. Sometimes it is yet helpful to look not only at the dQs and the accumulated differences $d Q$. Fig. 8 seems to confirm further the reliability of the rainfall-runoff models. It may occur during the eventual puzzles in the analyses of some hydrological series and looking at the diversities in the flow duration curves can be helpful.

The results of differences $d Q$ and sum $d Q$ from the remote experimental catchments in the Labe River basin in Fig. 9 illustrate also the abrupt and random events occurring as the visible phenomena: as the deformation of stream channel after the flood, or the exchange of equipment for the flows monitoring.

Nevertheless the rainfall-runoff modelling provides as the outputs the results, which could be very similar also with diverse types of tools (see Fig. 10). Of course, the different modelling tools could help to identify the diverse changes and the hydrological model has been used extensively, which provides the simulations of runoff components as presented in Fig.1l, with the examples of large variety of runoff parts. 


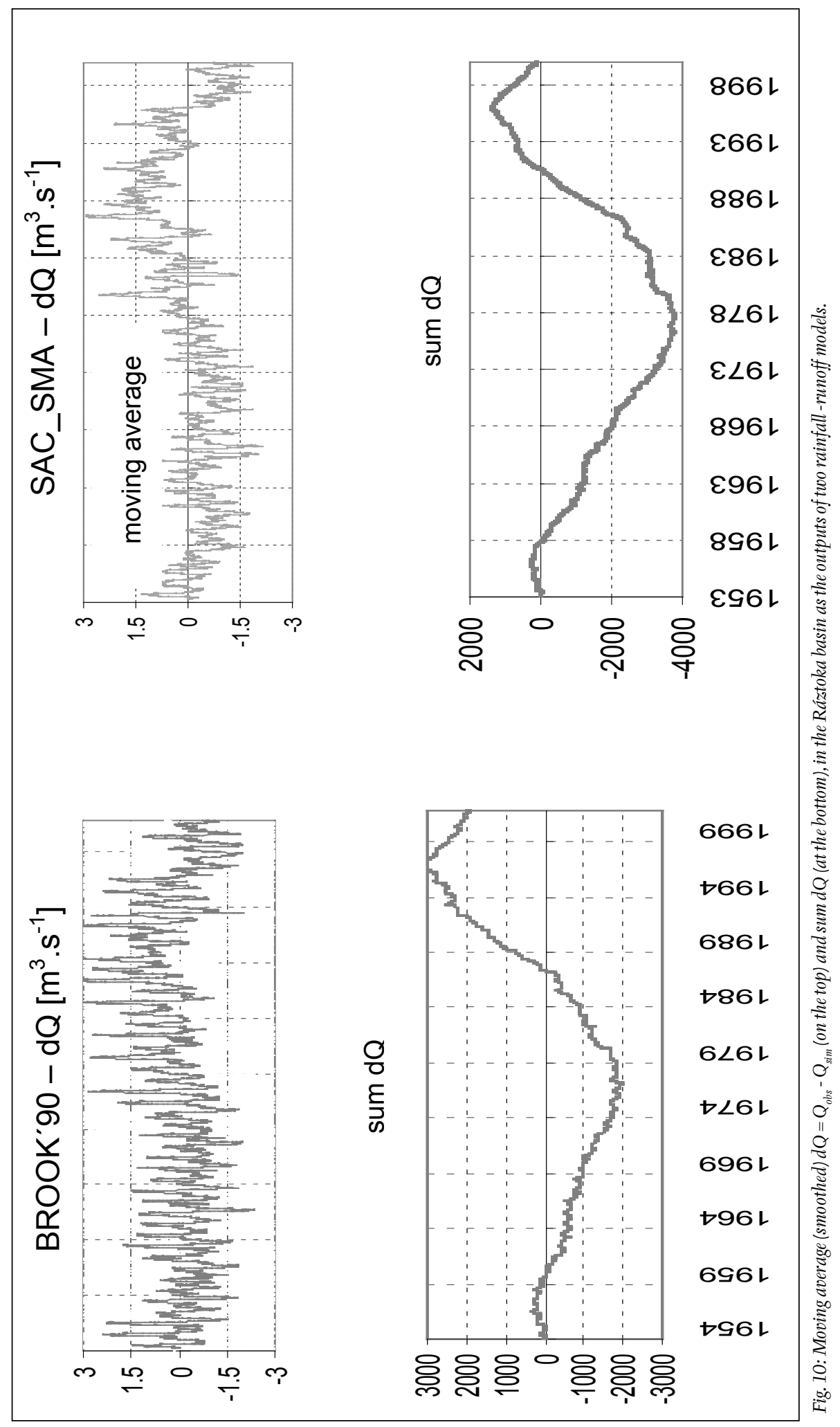




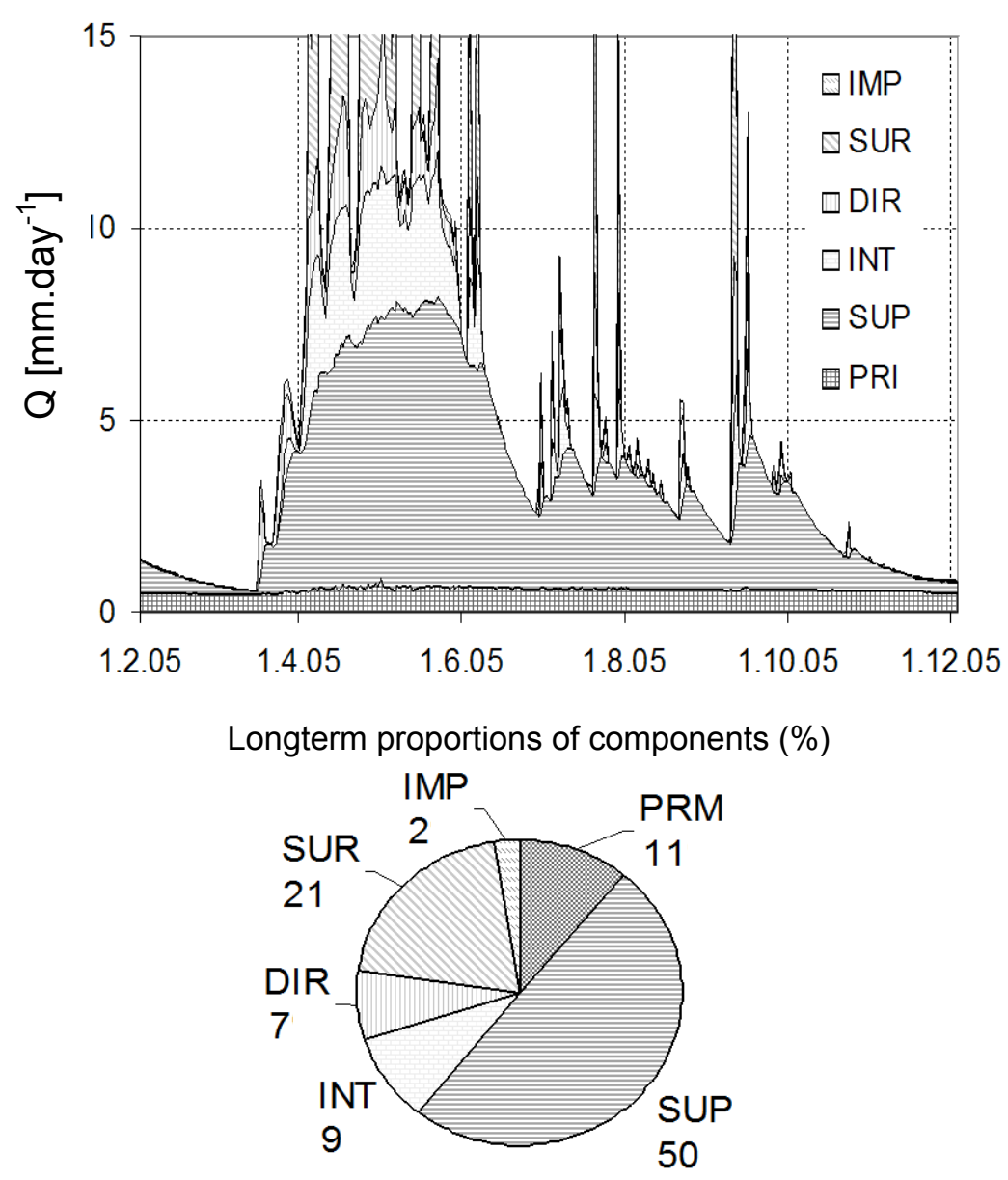

Snowmelt flows in year 2005 (I.-VI.) (\%)

Floods in July 1997 (\%)
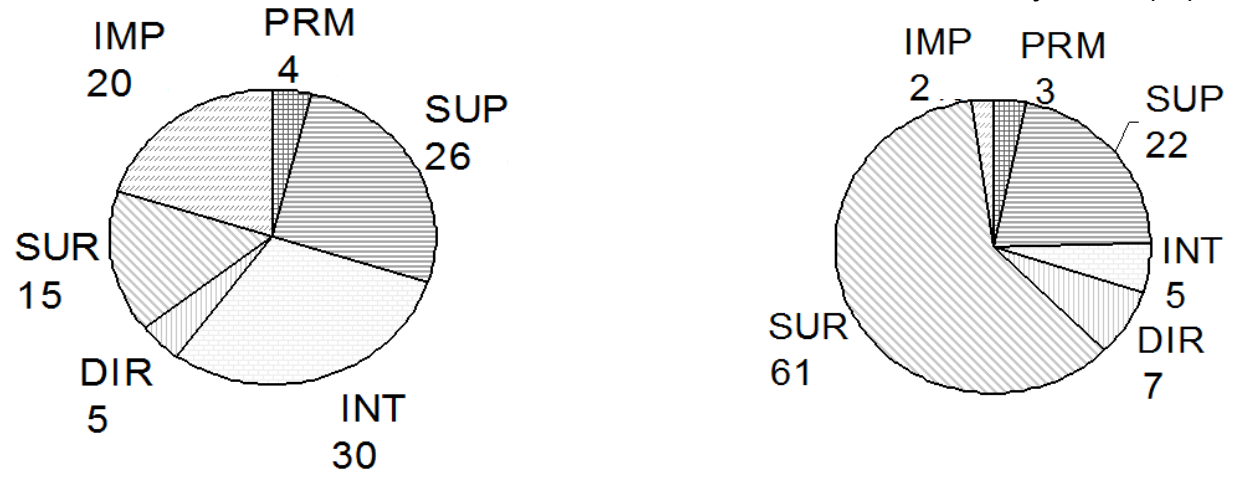

baseflows: primary, supplementary, interflow

other outflows: direct, surface, from impervious areas

Fig. 11: Simulated runoff components for the Modrý potok basin in the Giant Mts. 


\section{Conclusions}

The simulations of the rainfall-runoff process appeared as helpful in the efforts to follow the effects of vegetation evolution, as one of the natural causes for long-term fluctuation in water resources. The significant reason for the fluctuations in water regime could be frequent natural oscillation and also the changeable solar radiation on the scale of tens of years, which might affect both evapotranspiration and precipitation variability, but also winds events.

The modelling is an appropriate tool for identification of diverse alterations in water regime besides vegetation change. The course of differences between observed and simulated discharge permits to follow the dynamics in existing changes. The uncertainty could arise namely when the change is gradual and/or when some random and abrupt change in the basin appears.

\section{Acknowledgement}

The research has been supported by the Technology Agency of the Czech Republic (project No. TA02021451) and by the Czech Science Foundation (project No. 205/09/1918). Hydrological and hydrometeorological data, namely for experimental basins in the Beskydy Mts. with long-term monitoring, have been available due to cooperation with persons responsible for the operation of monitoring and participated in joint publications.

\section{References}

Armbruster M., SeEgert J., Fegert K.H. 2004: Effects of changes in tree species composition on water flow dynamics - Model applications and their limitations. Plant and soil, 264: 13-24.

BEER, J. 2005: Solar variability and climate change, Global Change NewsLetter, 63: 17-20.

BRÁZDIL, R. a kol.: 2005: Historické a současné povodně v České republice. [Historical and recent floods in the Czech Republic] Historie počasí a podnebí v České republice sv. VII, MU Brno, ČHMÚ Praha, IBSN 80-210-3864-0.

Brandt, M., Bergström, S., Gardelin, M. 1988: Modelling the effects of clearcutting on runoff - examples from central Sweden. Ambio, 17 (5): 307-313.

Buchtele, J., KošKová, R., JaŘabÁč, M. 2004: Analysis of water regimes in two experimental basins in Beskydy Hills. Proceedings of the Adolf Patera Workshop 2004 - "Extreme hydrological events in catchments" (Eds. BROŽA, V.,
VÁšKa, J., Jakubíková, A.), Prague, December 2004, ISBN 80-01-03161-6: 173-180.

Buchtele, J., Tesař, M. 2009a: The time variability of evapotranspiration and soil water storage in long series of rainfall-runoff process. Biologia, 64 (3): 575-579.

Buchtele J., Tesař M., KRÁm P. 2009b: Variability of the water regime in forested experimental catchments. Soil and Water Research, 4 (Special Issue 2): 93-101.

Buchtele, J., Tesař, M. 2010: Simulation of a rainfall-runoff process for the evaluation of variability in the river flow regime in small basins with vegetation changes. Folia Geographica, XLI: 103-110.

Burnash, R.J.C. 1995: The NWS River Forecast System - Catchment modelling. In: Singh,V.P. (ed.) Computer Models of Watershed Hydrology. Water Resources Publ., 1144 pp.

FEDERER, C.A. 1993: BROOK 90 - A Simulation Model for Evapotranspiration. Soil Water and Streamflow. USDA Forest Service, Durham, New Hampshire, USA, 19: 84 pp.

JeLíneK, J. 1985: Větrná a kůrovcovitá kalamita na Šumavě z let 1868-1978, [Wind and insect disasters in Šumava Mts. in years 18681878], Výzk.zpráva Lesprojekt.

KeLler R. 1970: Water-balance in the Federal Republic of Germany, Symposium World Water Balance, UNESCO/IAHS Reading, Publ., 92: 300-314.

SCHAFFeRnaK, F. 1935: Hydrographie, Verlag von J. Springer, Wien, $547 \mathrm{pp}$.

http://en.wikipedia.org/wiki/Atlantic_Multidecadal _oscilation 
